\title{
The distribution of air temperature and velocity in the selected boiler room
}

\author{
Robert Cichowicz ${ }^{1, *}$, and Artur Stelęgowski ${ }^{1}$ \\ ${ }^{1}$ Lodz University of Technology, Faculty of Architecture, Civil and Environmental Engineering, \\ Al. Politechniki 6, 90-924 Łódź, Poland
}

\begin{abstract}
The crucial impact on the indoor air quality in technological rooms, including boiler plant buildings, is made by operation of technological devices and ventilation systems. Therefore, the distribution of air temperature and velocity in these rooms mainly depends on location and heat gains generated by combustion devices, as well as emplacement of air supply and air exhaust elements. The temperature and airflow volume of supplied air is also an issue, because the indoor environment parameters are formed by the flow of air in the working area. Determination of the impact of physical factors on the thermal environment in a room is possible using an analysis of the air temperature and velocity. This issue is vital in terms of necessity to maintain the adequate heat conditions in the working area. Therefore, basing on the experimental measurements and numerical calculations (made in DesignBuilder software), the distribution of air temperature and velocity was analyzed in the selected industrial boiler room, located in the Lodz city, in Poland. The results obtained were compared with the recommended and limit values in the industrial buildings.
\end{abstract}

\section{Introduction}

Although the issue of distribution of air temperature and velocity has been repeatedly studied and discussed for non-residential buildings [1-3], unfortunately, there is lack of information about industrial boiler rooms. However, there are publications on indoor air quality in industrial buildings, where the internal conditions are significantly affected by the operation of technological equipment, and related to the estimation of thermal comfort of employees [4, 5], and the functioning of industrial ventilation [6, 7]. In consequence, modernly, when designing non-air-conditioned industrial rooms, it is recommended to adopt conditions as for office rooms [8], using appropriate standards for thermal comfort [9] and thermal loads [10]. Whereas, in older publications, the temperature recommendations for industrial rooms were being applied [11]. Nevertheless, there is a lack of studies on thermal conditions in boiler rooms, where workers are exposed to temporary exposure to high temperatures associated with the operation of fuel combustion installations. Unfortunately, regarding the recommended air temperature and velocity, there is also a lack of studies, that can be used as a guideline for the design of this type of rooms.

*Corresponding author: robert.cichowicz@p.lodz.pl 
Whereas, scientific researches have shown that interdependence of those two figures can determine improved or deteriorated human thermal sensation [12] and cause an increase or decrease in employee productivity [13]. In addition, exposure of workers to high temperatures (WBGT above $30^{\circ} \mathrm{C}$ ), associated with work with thermal equipment, causes both a decrease in productivity, as well as an increase in the number of health leave, extension of tasks and irritation of employees [14].

According to recommendations [8], the air temperature in a non-conditioned room in summer should be below $25^{\circ} \mathrm{C}\left(28^{\circ} \mathrm{C}\right.$ is allowed for a period not longer than $1 \%$ of total hours per year [8]), and in industrial rooms with high heat gains it should be always below $28^{\circ} \mathrm{C}$ [11]. An additional temperature criterion for this type of rooms is to not exceed the $5 \mathrm{~K}$ difference between internal and external air temperature [11]. What is more, the temperature difference between air at head and leg height should not exceed $3 \mathrm{~K}$ [8]. Also, in accordance with the recommendations [11], the air velocity in the working zone should be below $0.30 \mathrm{~m} / \mathrm{s}$ as optimal, and below $1.00 \mathrm{~m} / \mathrm{s}$ as permissible for light and medium work [11]. Knowledge of air temperature and velocity in industrial rooms enables an assessment of thermal and quality conditions of air in terms of work of personnel operating process lines [6]. These criteria are also vital in technological rooms not intended for permanent presence of people (inter alia in boiler rooms), where the time spent by employees can be up to two hours [15]. Work of technological equipment in industrial buildings is often associated with the emission of particulate matter and gas pollution [16], as well as with the release of heat and moisture. Therefore, in the condition of high thermal power of process equipment and small encapsulation of technological processes, a significant amount of heat and various types of contaminants enter the room.

\section{Method description}

The analysis of air temperature and velocity was made for the technological room in an industrial boiler plant building of $8.14 \mathrm{MW}$ thermal power, which is the Sewage Sludge Thermal Treatment Plant (ITPO). It is located in the Group Sewage Treatment Plant in Lodz city, in Poland, and is treating the sewage from the Lodz Agglomeration. The ITPO is an element of sludge management and due to its thermal capacity (between $1 \mathrm{MW}$ and $50 \mathrm{MW}$ ) it is classified as a "medium combustion plant" [17]. The utilization of dried sewage sludge is carried out in the technological room of the sludge processing hall, by burning in the industrial furnaces, that are based on the fluidized bed technology [18-20].

The room analyzed has $718.10 \mathrm{~m}^{2}$ area and approximately $16.90 \mathrm{~m}$ height. It is equipped with a general ventilation system and technological equipment for thermal treatment of sewage sludge, operating in a system of two identical, independent process lines of 4.07 MW thermal power each. They consist of, among others, fluidized bed furnaces, recuperators, boilers, multicyclones, flue gas cooling devices, bag filters and stacks (fig. 1). The temperature inside the process equipment is from $190^{\circ} \mathrm{C}$ in the chimney to $870^{\circ} \mathrm{C}$ in a fluidized bed furnace. Due to their height, the devices are operated from the working platforms located at the height from $0.00 \mathrm{~m}$ to $11.60 \mathrm{~m}$. 


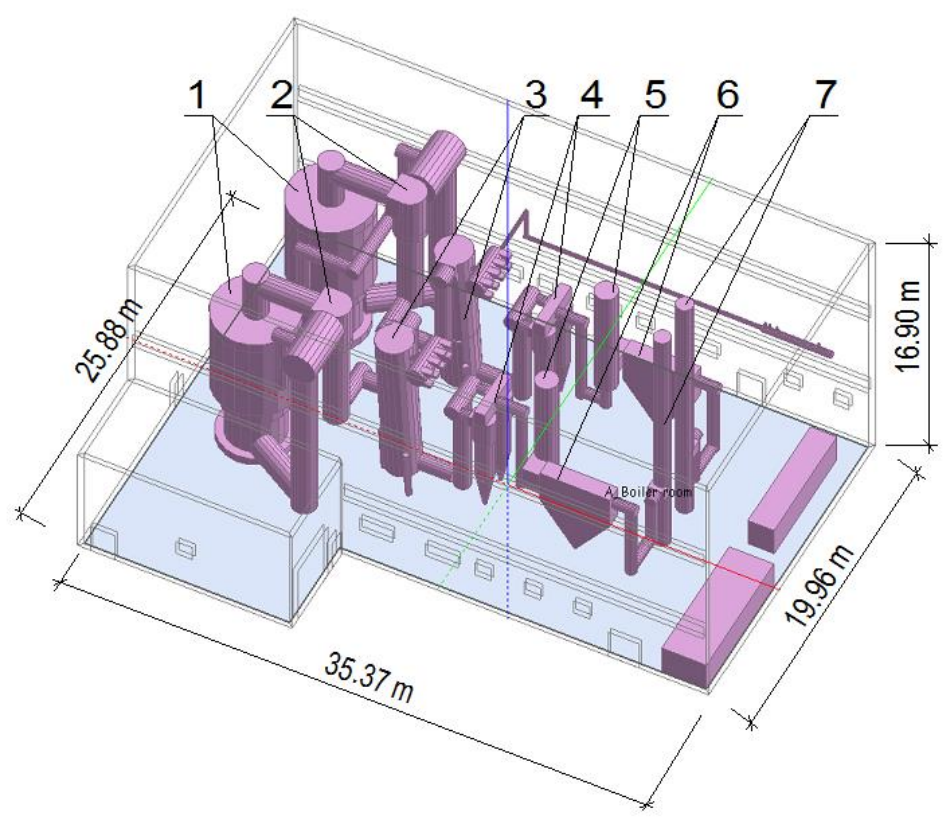

Fig. 1. Technological equipment in the boiler room, where: 1 - furnace, 2 - recuperator, 3 - boiler, 4 - multicyclone, 5 - flue gas cooling device, 6 - bag filter, 7 - stack.

The general ventilation in the room operates on the basis of 12 identical roof exhaust fans, of $800 \mathrm{~mm}$ nominal diameter and $15000 \mathrm{~m}^{3} / \mathrm{h}$ nominal airflow, and located above the main technological devices. The fresh air is supplied through 13 wall intakes, of $2000 \mathrm{~mm}$ per $1000 \mathrm{~mm}$ and $1000 \mathrm{~mm}$ per $1000 \mathrm{~mm}$ dimension, and placed in external walls at the $2.49 \mathrm{~m}$ height.

The room model and numerical calculations of air parameters were made in the DesignBuilder program, using the Finite Volume Method for CFD analysis. After the geometrical model was created, the considered area was divided by means of a finite volume grid into more than 2.9 million cells.

Additionally, in order to determine the boundary conditions for numerical calculations and to validate the model, experimental measurements were made during the summer season. Only one process line operated during the measurements. The surface temperature of the process equipment was measured with a radiation pyrometer with an accuracy of $\pm 1^{\circ} \mathrm{C}$. It ranged from $37.0^{\circ} \mathrm{C}$ (in the lowest part of the device for cooling the exhaust gases) to $117.6^{\circ} \mathrm{C}$ (in the highest part of the fluidized bed furnace). The air velocity in the cross-section of exhaust fans was measured with an anemometer and it amounted to an average of $9.80 \mathrm{~m} / \mathrm{s}$ in $0.297 \mathrm{~m}^{2}$ cross-section net area. Since only nine out of twelve exhaust fans operated during the measurements, the total ventilation airflow was $97020 \mathrm{~m}^{3} / \mathrm{h}$. This provides approximately eight air changes per hour. The surface temperatures of the room partitions were obtained as a result of the building's energy calculations, and the outdoor air temperature was read from the meteorological station and it was $23.3^{\circ} \mathrm{C}$. The relative humidity in the room was measured using a psychrometer with an accuracy of $2 \%$, and was from $24.1 \%$ to $38.1 \%$. After introducing the boundary conditions into the geometric model (table 1), numerical calculations were carried out using the "k- $\varepsilon "$ turbulence model type and the "Power-Law" discretization scheme [21]. The calculation residue was $10^{-5}$. In order to verify the results of numerical calculations and to validate the model, the experimental measurements of air temperature in five different points of the room were made using a psychrometer with an accuracy of $\pm 0.19 \mathrm{~K}$. 
Table 1. Boundary conditions for CFD model.

\begin{tabular}{|c|c|}
\hline Boundary condition & Value \\
\hline Outdoor air temperature & $23.3^{\circ} \mathrm{C}$ \\
\hline Total ventilation airflow & $97020 \mathrm{~m}^{3} / \mathrm{h}$ \\
\hline Temperature of equipment surfaces & $37.0-117.6^{\circ} \mathrm{C}$ \\
\hline Temperature of partitions & $18.0-33.8^{\circ} \mathrm{C}$ \\
\hline
\end{tabular}

\section{Results}

The results of numerical calculations were compared with the results of experimental measurements. This allowed to verify the correctness of the model's execution. In the CFD analysis the error of comparing results of numerical calculations with experimental measurements is usually not more than $\pm 10 \%[22,23]$ and in the analyzed case it was from $-5.0 \%$ to $+7.6 \%$. Therefore, it was assumed that the obtained results are correct and reliable.

The CFD analysis allowed to determine the air temperature and velocity distribution in the boiler room at different work heights, inter alia at all existing work platforms from $\pm 0.00 \mathrm{~m}$ to $+11.60 \mathrm{~m}$. Three different locations (PA1-PA3) were selected for the analysis in the work area of people operating the technological equipment, always at the height of the ankles $(0.10 \mathrm{~m})$ and at the height of the head of employees serving this room $(1.70 \mathrm{~m})$. The location of PA1 was between fluidized-bed furnaces, while PA2 and PA3 were on the communication route. Therefore, it was observed, that at $23.30^{\circ} \mathrm{C}$ of outdoor air temperature, the air temperature in the room increases of approximately $0.63 \mathrm{~K} / \mathrm{m}$ along with height, and it was from $20.36^{\circ} \mathrm{C}$ to $28.86^{\circ} \mathrm{C}$ in the work zones (fig. 2).

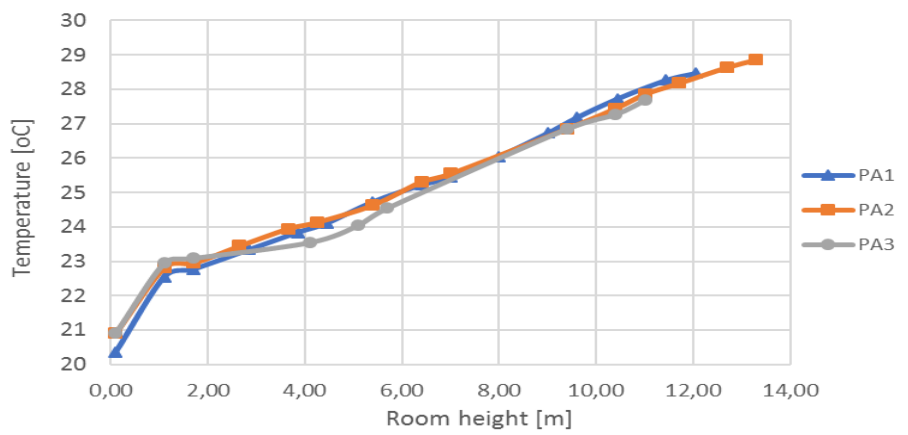

Fig. 2. Air temperature in function of height of employees work area.

However, in a close proximity (up to $0.5 \mathrm{~m}$ ) to technological equipment, as well as under the roof of the room, that is outside the work zone, the air temperature exceeded $30^{\circ} \mathrm{C}$. At the same time, at the $0.10 \mathrm{~m}$ above floor level it did not exceed $22^{\circ} \mathrm{C}$ on the majority (approximately 90\%) of the room analyzed. Higher temperatures at this height occurred only in the central part of the room and this was related to the supply of warmer air, "reflected" from hot surfaces of technological equipment. Which indicated the mixing of air in this part of the boiler room. However, at the $+13.30 \mathrm{~m}$ level, the air temperature exceeded $28^{\circ} \mathrm{C}$ in about $95 \%$ of the area, and in the vicinity of the furnace, the recuperator and the boiler of the operating technological line, it was over $30^{\circ} \mathrm{C}$. This was associated with high surface temperature of these devices, reaching $117.6^{\circ} \mathrm{C}$. The air in their vicinity warmed up and rose due to the phenomenon of natural convection, which is characteristic for the air stratification. As a consequence, the distribution of air velocity in the room was very uneven. The air velocity in the work area it ranged approximately from 0.09 to $0.36 \mathrm{~m} / \mathrm{s}$ (fig. 3), and reached the highest values approximately from $0.10 \mathrm{~m}$ to $4.00 \mathrm{~m}$ 
height, which was related to the supply of fresh air through air intakes, mounted in the external walls. The lowest values were found in the zone beyond the influence of ventilation and on higher (more than $6 \mathrm{~m}$ ) working levels.

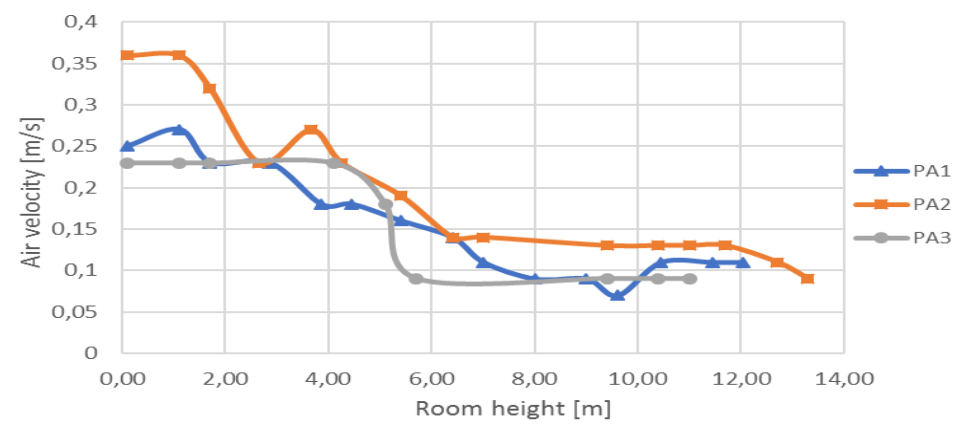

Fig. 3. Air velocity in function of height of employees work area.

At the $+2.65 \mathrm{~m}$ level (fig. 4), corresponding to the location of air intakes, the supplied air was flowing into the room at speed exceeding $1.00 \mathrm{~m} / \mathrm{s}$ at even $9 \mathrm{~m}$ length. This resulted in air turbulence and its flow around the hot surface of technological equipment. As a consequence, the air supplied was accumulating heat generated during the operation of combustion units. Air turbulence indicated, at this level, the dominance of mixing strategy, associated with dilution of contaminants and low efficiency of process heat gains removal. Uneven distribution of the air velocity in the boiler room also occurred in the cross-section through the air intakes. The air flowed through the intakes with about $1.87 \mathrm{~m} / \mathrm{s}$ velocity, which resulted in exceeding $0.20 \mathrm{~m} / \mathrm{s}$ in the work area in the central part of the room. In addition, there was an increase in air velocity over operating technological devices, and this was related to the occurrence of convection. However, roof fans had a negligible effect on the air velocity in the work zones due to the small range of their operation, which resulted in lower air velocity in higher work zones (from approximately $6 \mathrm{~m}$ ).

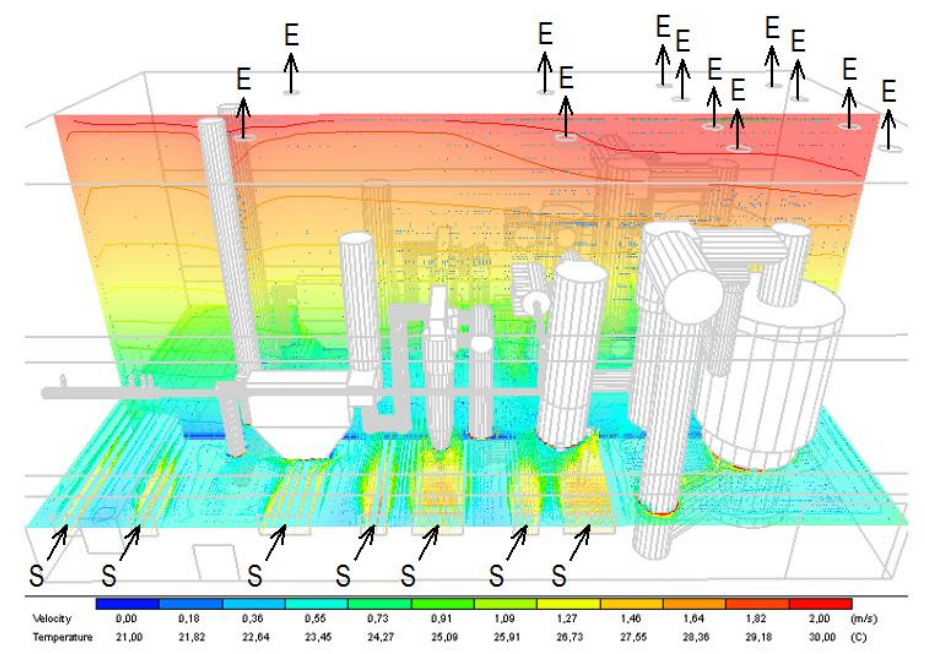

Fig. 4. Distribution of air temperature and velocity in the room, where: S - air supply, E - air exhaust. 


\section{Conclusions}

The recommended air temperature in the work zone of people in an industrial non-conditioned building depends on the level of metabolic activity of workers. In the season analyzed (in the summer) it is $25^{\circ} \mathrm{C}$ for light work and $23^{\circ} \mathrm{C}$ for medium work [11]. The permissible temperature is $28^{\circ} \mathrm{C}$ [8] and the indoor air temperature should not exceed the outdoor temperature by more than $5 \mathrm{~K}$ [11]. However, at the $23.3^{\circ} \mathrm{C}$ of outdoor air, the indoor air temperature in the boiler room differed from the outside of a value from $-2.94 \mathrm{~K}$ to $+5.56 \mathrm{~K}$, and it locally exceeded even $30^{\circ} \mathrm{C}$. This indicates that the recommended temperature criterion has not been met from approximately $6 \mathrm{~m}$ height and the permissible values were exceeded above $11.60 \mathrm{~m}$ height, that is in the highest working zone in the boiler room. Assuming that the indoor air temperature in the room will increase during the summer along with the outdoor air temperature, the estimated number of excesses of permissible temperature (based on statistics of air temperature in the city of Lodz) will amount to 363 hours, which is less than $1 \%$ of the year. However, the temperature difference between the head and ankles of the employee in the analyzed room was below $2.5 \mathrm{~K}$ and did not exceed the recommended value of $3 \mathrm{~K}$ [8]. Therefore, the room temperature criteria are considered to be partially fulfilled.

Optimal air velocity in an industrial plant is $0.3 \mathrm{~m} / \mathrm{s}$, and the limit value is $0.7 \mathrm{~m} / \mathrm{s}$ for light work and $1.0 \mathrm{~m} / \mathrm{s}$ for medium work [11]. In the room analyzed the air velocity was $0.09-0.36 \mathrm{~m} / \mathrm{s}$ in the work zone. Therefore, the criterion was partially preserved, even though the air velocity locally exceeded $1.00 \mathrm{~m} / \mathrm{s}$ outside the work area. Nevertheless, it is advisable to increase the air velocity in the work zones, where the air temperature exceeds the recommended values. Since the increase of $0.8 \mathrm{~m} / \mathrm{s}$ may result in the improvement of thermal sensations at temperature rise even by $5.6^{\circ} \mathrm{C}$ [24]. This desired phenomenon of the increase of cooling effect is associated with air movement in a warm environment $[25,26]$.

The distribution of air in the boiler room analyzed was characterized by the dominance of air mixing in its lower part, and the phenomenon of stratification/natural convection in the upper part. The mixing of air resulted from the high velocity of fresh air flowing into the room through the intakes and the air temperature increased as a result of heat exchange with technological equipment. However, the rise of air temperature and velocity in the surroundings and over the devices resulted from the convection of heated air.

Operation of the ventilation system provided the acceptable air temperature and velocity in most of the work area in the boiler room analyzed. However, it did not provide a sufficient effectiveness of removal or dilution of heat that was coming from the operation of the technological equipment. This resulted in excesses of the permissible temperature in the highest work zone.

In the upper zones of the room, the buoyancy of air was associated with a phenomenon, unfavorable for workers, of the temperature rise along with the room height, that is with the stratification of air [27]. Increasing the ventilation airflow and encapsulation of industrial processes would provide better indoor air quality. In addition, the use of local exhaust ventilation, cooperating with general ventilation system, should enable more efficient dissipation of heat that is generated as a result of technological processes [6].

The performed CFD analysis allowed to determine the air temperature and velocity in the work zone of people in the selected room of the industrial boiler plant. Consequently, this allowed to assess the operation of industrial ventilation and thermal conditions inside the boiler room, and therefore it helps to optimize the work conditions in this type of industrial boiler plants. It has been also demonstrated that numerical calculations can be successfully used to analyze air parameters, the knowledge of which is the basis for the assessment of the functioning of technical solutions that are related to the air quality in industrial buildings. 


\section{References}

1. S.H. Ho, L. Rosario, M.M. Rahman, International Journal of Refrigeration 33

2. A.K. Melikov, U. Krüger, G. Zhou, T.L. Madsen, G. Langkilde, Build. Environ. 32

3. X. Wu, Y. Liu, G. Liu, F. Wang, Z. Wang, Energy Procedia, 121 (2017)

4. N. de Melo Pinto, A.A. de Paula Xavier, K. Hatakeyamac, Procedia Manufacturing 3

5. R. Kralikova, H. Sokolova, E. Wessely, Procedia Engineering 69, (2014)

6. ACGiH, Industrial Ventilation, A Manual Of Recommended Practice (American Conference of Governmental Industrial Hygienists, Ohio 1998)

7. H. Goodfellow, E. Tahti (Eds.): Industrial Ventilation. Design Guidebook (Academic Press, San Diego 2001)

8. CIBSE, CIBSE Guide A: Environmental Design (The Chartered Institution of Building Services Engineers London, Norfolk 2006)

9. ISO 7730 (2005), Ergonomics of the thermal environment - Analytical determination and interpretation of thermal comfort using calculation of the PMV and PPD indices and local thermal comfort criteria (International Organization for Standardization, 2005)

10. ISO 7243 (2017), Ergonomics of the thermal environment - Assessment of heat stress using the WBGT (wet bulb globe temperature) index, (International Organization for Standardization, 2017)

11. M. Malicki, Ventilation and Air-Conditioning (PWN, Warsaw, 1974)

12. S. Wijewardane, M.T.R. Jayasinghe, Renewable Energy 33, 2057-2063 (2008)

13. W. Cui, G. Cao, J.H. Park, Q. Ouyang, Y. Zhu, Build. Environ. 68, 114-122 (2013)

14. M. Krishnamurthy, P. Ramalingam, K. Perumal, L.P. Kamalakannan, J. Chinnadurai, R. Shanmugam, K.Srinivasan, V. Venugopal, Safety and Health at Work 8, 99-104 (2017)

15. Polish Regulation Of The Minister Of Infrastructure of 12 April 2002 on technical conditions, which should correspond to the buildings and their location (Rozporządzenie Ministra Infrastruktury w sprawie warunków technicznych, jakim powinny odpowiadać budynki i ich usytuowanie z dnia 12 kwietnia 2002 r.)

16. R. Cichowicz, G. Wielgosiński, A. Targaszewska, Ecol. Chem. Eng. S 23, 49-60 (2016)

17. Directive (EU) 2015/2193 of the European Parliament and of the Council of 25 November 2015 on the limitation of emissions of certain pollutants into the air from medium combustion plants

18. J. Van Caneghema, A. Brems, P. Lievens, C. Block, P. Billen, I. Vermeulen, R. Dewil, J. Baeyens, C. Vandecasteele, Prog. Energy Combust. Sci. 38, 551-582 (2012)

19. A.A. Khan, W. de Jong, P.J. Jansens, H. Spliethoff, Fuel Process. Technol. 90, 21-50 (2009)

20. S.I. Perez-Elvira, P. Nieto Diez, F. Polanco, Reviews in Environmental Science and Bio/Technology 5, 375-398 (2006)

21. ASHRAE, Handbook. Fundamentals (American Society of Heating, Refrigerating and Air-conditioning Engineers, Inc., Atlanta 2009)

22. G. Einberg, K. Hagstrom, P. Mustakallio, H. Koskela, S. Holmberg, Build. Environ. 40, 601-615 (2005) 
23. S. Varga, A.C. Oliveira, X. Ma, S.A. Omer, W. Zhang, S.B. Riffat, International Journal of Low-Carbon Technologies 6, 119-124 (2011)

24. B.W. Jones, K. Hsieh, M. Hashinaga, ASHRAE Trans. 92, 761-769 (1986)

25. L.G. Berglund, Thermal Comfort, in: H. Goodfellow, E. Tahti (Eds.): Industrial Ventilation. Design Guidebook, pp. 174-193 (Academic Press, San Diego, 2001)

26. Y.Z. Xia, J.L. Niu, R.Y. Zhao, J. Burnett, Indoor Air 10, 289-296 (2000)

27. B. Biegert, J. Railio, Terminology, in: H. Goodfellow, E. Tahti (Eds.): Industrial Ventilation. Design Guidebook, pp. 9-14 (Academic Press, San Diego, 2001) 